\title{
An Assessment of Key Human Resource Management Practices on Job Satisfaction among Senior Staff of The University Of Cape Coast, Ghana
}

\author{
Emmanuel Tchouchu (Corresponding author) \\ School of Business Studies, University of Cape Coast \\ PMB, UCC Campus, Cape Coast, Ghana
}

Received: Jan. 24, 2022 Accepted: Feb. 24, 2022 Online published: Mar. 1, 2022

doi:10.5296/ijhrs.v12i1.19504ＵRL: https://doi.org/10.5296/ijhrs.v12i1.19504

\begin{abstract}
Human resource management (HRM) practices play crucial roles in guaranteeing that organizations provide quality services. This paper assessed the effect of selected key HRM practices on employees' job satisfaction at the University of Cape Coast. Using an explanatory design, 302 respondents were sampled out of 1469 senior staff of the University through a stratified random sampling technique. The main instrument used for data collection was the questionnaire. 292 respondents answered the questionnaires, which represented $96.68 \%$ of the responses rate. The Statistical Product for Service Solution (SPSS) was employed to analyze data. The dependent variable was job satisfaction. The independent variables were promotion, reward, training and development, and supervision. Pearson correlation was used to determine the relationships among the variables, and the standard multiple regression test was used to determine the level of significance of each determinant of job satisfaction. The results of the analysis show that promotion, reward, training and development, and supervision have a moderate effect on job satisfaction; but supervision and reward have a significant positive effect on employees' job satisfaction. The study contributed to knowledge in the research endeavor by demonstrating that although HRM practices influence job satisfaction among employees of the University of Cape Coast, promotion does not automatically make all employees enjoy their jobs.
\end{abstract}

Keywords: job satisfaction, promotion, reward, training and development, supervision

\section{Introduction}

Generally speaking, HRM practices play a vital role in guaranteeing quality services from the organizations. Being a set of policies that increase the firm's human capital to attain business goals (Gürbüz, 2009), HRM creates a means of safeguarding positive employee and job satisfaction relationships. On the global scale, several studies (Absar et al., 2010; Bharadwaj, 
2015 and Farahbod \& Arzi, 2014) have shown that there is a significant relationship between HRM practices and employees' job satisfaction, which is one of the key influences that foster the organization's performance. This indicates that a kind of HRM practice that puts individuals first is required to satisfy those working in the organization. Thus the employees may enjoy their job based on how the management of an organization treats them.

In their various studies, scholars such as Segbenya and Ansah (2020), Božović, Božović, and Ljumović (2019), and Antwi et al. (2016) examined the influence of HRM practices on employees' job satisfaction in the banking industry. Farahbod and Arzi (2014), and Igbal et al. (2013) evaluated the influence of HRM practices on employees' job satisfaction in both manufacturing and hotel companies. The results indicated that HRM practices either have a positive effect or a negative one on workers' job satisfaction. The employees, who transact the main business of the organization, are at the center of HRM practices and can help sustain the organization's competitive advantage (Syed \& Yah, 2012). Hence Oyeniyi, Afolabi, and Olayanju (2014) observed that HRM, in playing its main functions, must invest in employees' training, boost up participation in decision-making, provide both promotion opportunities for all workers, and suitable rewards.

One of the main reasons why HRM practices must invest in individuals is that staffs play a significant role in each organizational setup. Organizational goals may not be realized if the employees are not rightly motivated to perform their jobs since most work in establishments is done by human beings. For such a reason, Bharadwaj (2015) opined that any organization that seeks to gain a competitive advantage in today's volatile economy must pay attention to how HRM practices are being used to manage human resources (employees). Niazi (2014) concurs with Bharadwaj's view as he observed that individuals are the foundations of success in all organizations. Hence if workers are pleased with the jobs as well as the work environment, that organization is likely to thrive.

Among the studies that looked at the nexus between HRM practices and employees' job satisfaction, few (Kosi et al, 2015; Saani \& Tawiah, 2017, Soale \& Akudugu, 2021) has been done in the institutions of higher learning- Colleges of Education, Universities, and Polytechnics - usually referred to as knowledge-based institutions. Kosi, Opoku-Danso, and Ofori (2015) discovered that fairer remuneration and reward system enhances retention of hard-working employees UCC. Saani and Tawiah (2017) observed that the compensation package only boosts the level of satisfaction and commitment of Junior Staff of UCC, which in turn can increase their work performance. Soale and Akudugu (2021) discovered that changes in the workers' attitudes account for about $43 \%$ of senior staff's performance. However, all these studies did not consider the combined effect of more than one HRM practice on employees' job satisfaction in public tertiary institutions. Hence the current study looks at how key HRM practices affect senior staff's job satisfaction in UCC.

\section{Literature Review}

\subsection{Social Exchange Theory}

The nature of the world is such that people engage in many exchanges daily in groups, 
networks, organizations, and institutions. This justifies the proliferation of exchange theory as one of the major theories that underpin social interaction and social structure (Homans, 1958; Blau, 1964; Emerson, 1976). Homans (1961) sees the theory as the give-and-take activity between at least two persons. The fundamental concept of the theory is that human decisions and behavior are the results of cost and reward relationships. Blau (1964) observed that the principle of social exchange is such that one person does another a favor, and while there is a general expectation of some future return, its exact nature is not stipulated in advance. In exploring the theory, Emerson (1976) developed a psychological basis for exchange based on reinforcement principles. This makes the theory a socio-psychological theory of social behavior in which the relationship between two parties exists based on a cost-benefit analysis.

Homans (1961), Blau (1964), and Thibaut and Kelley (1959) have argued that the social exchange theory applies to both behaviors of employees in organizations and interpersonal relationships. In delving into the nature of the social exchange, Blau (1964) admitted that the rewards received by individuals in a social exchange can either be intrinsic or extrinsic. Hence Molm et al. (2003) referred to the theory as a system of reciprocity since the level of effect is measured by the type of exchange and the degree of behavioral commitment. Mitchell et al. (2012) observed that give-and-take happens when individuals provide a reward for a cost without stipulating the detailed nature of compensation though having in mind that some form of repayment will occur sometime. They attributed the success of such exchanges to the result of established relationships before the exchanges.

However, Redmond (2015) has critiqued the social exchange theory based on its original propositions and assumptions. Firstly he argued against the assumption that human beings are very rational and calculating when they engage in relationships as the theory would want us to believe. Secondly, due to the restrictive roles played by social beings, the principles outlined in social exchange cannot be applied to all exchanges, especially the ones that happen with no options of negotiating costs and rewards. Lastly, social exchange theory is reductionist in that it explains human relations simply in terms of costs-benefits analysis, leaving several factors that may influence human interactions.

\subsection{Concept of Job Satisfaction}

According to Locke (1976) job satisfaction is a positive emotive state that comes from the appraisal of a worker's job (Giao, Vuong \& Tushar, 2020). This concurs with Parker's (2008) assertion that work satisfaction is solidly related to the positive mental and emotional disposition of employees. Thus work satisfaction involves feelings, attitudes, opinions, and sensations that workers have towards their work, colleagues, and organization (Pule et al., 2014, Polatcan \& Cansoy, 2019). Qasim, Cheema, and Syed (2012) observed that while job dissatisfaction occurs as a result of a negative attitude towards one's job, a positive attitude results in job satisfaction. Hence, HR managers need to develop appropriate HR policies and practices (reward, promotion, etc) that can induce positive employees' job attitudes to guarantee job satisfaction.

In their research, Vikram and Sayeeduzzafar (2014) referred to job satisfaction as a result of the various likes and dislikes that an employee experiences on the job. Thus Mensah (2013) 
opined that the output of the organization is intrinsically related to how workers feel about their job and how much they are satisfied with what they are doing. This could mean that organizations are likely to attain optimum output if the staff is treated well, which could drive them to contribute their quota for the growth of the organization (Vikram \& Sayeeduzzafar, 2014). In addition, the performance of organizations also depends largely on employees' skills, talents, and level of experience which can be obtained through training. Hence Khan (2010) proposed a people-centered approach in HRM practices with the hope to increase the organization's output and sustain a competitive advantage.

\subsection{Concept of HRM Practices}

\subsubsection{Promotion}

From the words of Hasan et al (2020) promotion enables employees to change their levels of work positions to higher ones. Studies have shown that organizations that fairly promote their workers based on merit stimulate the job satisfaction of their employees (Muhammad \& Akhter, 2010, Hasan, Afrin, Rahman \& Ahmed, 2020). Promotion opportunities stimulate staff to work hard toward the improvement and growth of firms. Nevertheless, Danish and Usman (2010), and Jehanzeb and Bashir (2013) rather suggested that promotion opportunities must be offered based on the skills, ability, and experience of workers. By so doing it will be easy to increase the efficiency of the workers and guarantee their job satisfaction. In addition, promotion secures the loyalty of the workers to the organization. Hence, if well applied, the promotion will boost the efficiency in work performance, which comes as the result of employees' commitment and job satisfaction (Osborne \& Hammoud, 2017).

However, in their study Elqadri and Priyono (2015) observed that promotion does not influence significantly job satisfaction. This result is similar to that of Lup (2017) who stated that although promotion increases work satisfaction in men, it does not do the same for women promoted to top managerial positions. Hence, job satisfaction often declines with women promoted to higher-level management. Thus, by clarifying the relationship between gender and job satisfaction in terms of promotion, (Elqadri \& Priyono, 2015; Lup, 2017) contributed to the literature on the gender gap in managerial representation. Hence the following hypothesis is considered:

\section{$H_{1}$ : There is a positive relationship between promotion and job satisfaction.}

$H_{0}$ : There is a negative relationship between promotion and job satisfaction.

\subsubsection{Reward}

A reward is a cumulative benefit that employees get for services rendered to the organization (Cross, 2019). A reward policy indicates what the employees receive as they devote their efforts and time towards the realization of the organization's goals. In his study, Eerde (2015) noted that financial rewards affect the motivational levels of employees in varying degrees. For such a reason, Salah (2016) and Manzoor, Wei, and Asif (2021) observed that a reward system, when well applied, potentially increases the energy level of the workers to perform assigned tasks diligently to realize the organization's desired objectives. This concurs with 
the assertion by Terera and Ngirande (2014) that a good reward system not only attracts, but also motivates, and helps retain hardworking workers of the organizations. Hence, Mensah (2013) noted that employees' retention and commitment increase when they are satisfied with the benefits and rewards received.

According to Gohari et al. (2013), to satisfy and retain hardworking employees, organizations must design an attractive reward system. Studies have shown that a reward system based on merit and hard work stimulates workers to do well (Agwu, 2013; Chepkwony, 2014). In the case of universities, the staff is usually rewarded based on educational levels, work knowledge, and sometimes particular aids to the growth of the organizations. However, when a reward system is unfairly designed, it can demoralize workers and negatively influence workers' output (Edirisooriya, 2014). Thus organizations must design a reward policy that will make employees feel they are treated fairly in terms of the reward that they are enjoying. Hence, Bharadwaj (2019) observed that a good reward package induces good behavior and stimulates the employees to satisfactorily accomplish assigned within the deadline. The following hypothesis will therefore be verified:

$\mathrm{H}_{2}$ : There is a positive relationship between reward and job satisfaction.

$H_{0}$ : There is a negative relationship between reward and job satisfaction.

\subsubsection{Training and Development}

Training and development are aimed to improve or build the present or future skills of the employees, which will enhance their contribution to the performance of the organization (Nassazi, 2013, Rodriguez \& Walters, 2017). This implies that training and development activities enable the workers to gain new skills and increase competencies. For such a reason, Mensah (2013) argued that training and development programs are fundamental in developing, nurturing, and strengthening employees' skills and abilities. Thus, organizations generate a group of competent staff to replace those who may either leave the company or be promoted to higher managerial levels by embarking on periodic training programs.

Johnson and Gueutal (2011) discovered that constant training programs enable organizations to adapt to new technological ways of doing business. At the university level, training and development programs such as seminars, workshops, and scholarships although costly and time-consuming have benefits to the workers and the organization and cannot be overemphasized (Khan et al., 2011). This implies that every viable organization must train and develop its employees whether through on-the-job training (Timsal et al., 2016) or off-the-job training (Malaolu \& Ogbuabor, 2013; Vasanthi \& Basariya, 2019). Hence Bharadwaj (2019) observed that employees feel indebted to the organization when they have been trained to acquire new skills and competencies. In addition, optimum efficiency, and expertise can be the products of the right training and development, which can lead to employees' job satisfaction (Johnson \& Gueutal, 2011; Kwenin, Muathe \& Nzulwa, 2013). The following hypothesis is considered:

$H_{3}$ : There is a positive relationship between training and development and job satisfaction. 
$H_{0}$ : There is a negative relationship between training and development and job satisfaction.

\subsubsection{Supervision}

Supervision is a vital determinant of organizations' performance (Osborne \& Hammoud, 2017; Almatrooshi, Singh \& Farouk, 2016; Khan, Nawaz \& Khan, 2013). This is justified by the fact that supervisors are very much knowledgeable about the job requirements and can help develop the competencies of the workers under them. Generally speaking, the supervisor is measured by the performance of those under his/her supervision. From the work of Qureshi and Hamid (2017), and Miao, Fayzullaev, and Dedahanov (2020), supervision has a positive outcome on work fulfillment. This concurs with the statement by Vann (2017), and Qian, Song, and Wang (2017) that poor supervision often results in employees' job dissatisfaction. For such a reason, Hannang et al (2020), and Nasution (2017) argued that the efficiency of the staff can be attributed to close supervision and monitoring of work.

In other studies, Ismail (2018) and Thobega (2007) assessed the association between work satisfaction and supervision amongst agricultural education teachers in Iowa based on some specific components of supervision, which include support, observation, and direction. They discovered that supervision is positively correlated to job satisfaction. However, they discovered that the selected constituents of supervision did not predict the intentions of the teachers to remain in the teaching job. In similar studies, Alam and Asim (2019) and Fukui, $\mathrm{Wu}$, and Salyers (2019) observed that supervision is significantly related to workers' job satisfaction, thus lowering employees; turnover rates. Thus the following hypothesis will be verified:

$H_{4}$ : There is a positive relationship between supervision and job satisfaction.

$H_{0}$ : There is a negative relationship between supervision and job satisfaction.

\subsection{Relationship between HRM Practices and Job Satisfaction}

HRM practices vary from one organization to another. Numerous studies (Igbal et al., 2013; Oyeniyi et al., 2014; Antwi et al., 2016) have been conducted in a bid to look at some key HRM practices that determine job satisfaction among employees in public corporate organizations. Globally, Igbal, Malik, and Ghafoor (2013) in their study identified supervision, participation in decision making, and compensation as elements of employees' job satisfaction in the corporate organizations in Pakistan. Farahbod and Arzi (2014) also conducted a study on the impact of HRM practices on workers' employment in Malaysian Hotels and identified training, staffing, reward, and performance appraisal as determinants of job satisfaction. Oyeniyi, Afolabi, and Olayanju (2014) conducted their study on the same subject matter in the banking industry in Nigeria. Compensation, supervisory, training, promotion, and evaluation were rather identified as determinants of work fulfillment.

In Ghana, Antwi et al. (2016) conducted research on the assessment of HRM practices on employees' job happiness in Ghanaian public banks. The following determinants of job satisfaction were identified- training, motivation, compensation, and in-house communication. 


\section{Macrothink}

In examining the influence of HRM practices on organizational performance at rural banks, Segbenya and Ansah (2020) identified that recruitment and selection, performance assessment, and worker participation strongly influenced employees' job satisfaction. Against such a background, the study will consider the following four (4) practices - reward, promotion, training and development, and supervision- as some key factors that can determine job satisfaction in universities.

\section{Conceptual Framework}

Having carefully reviewed the literature on the influence of HRM practices on workers' employment fulfillment, the following conceptual model has been formulated.

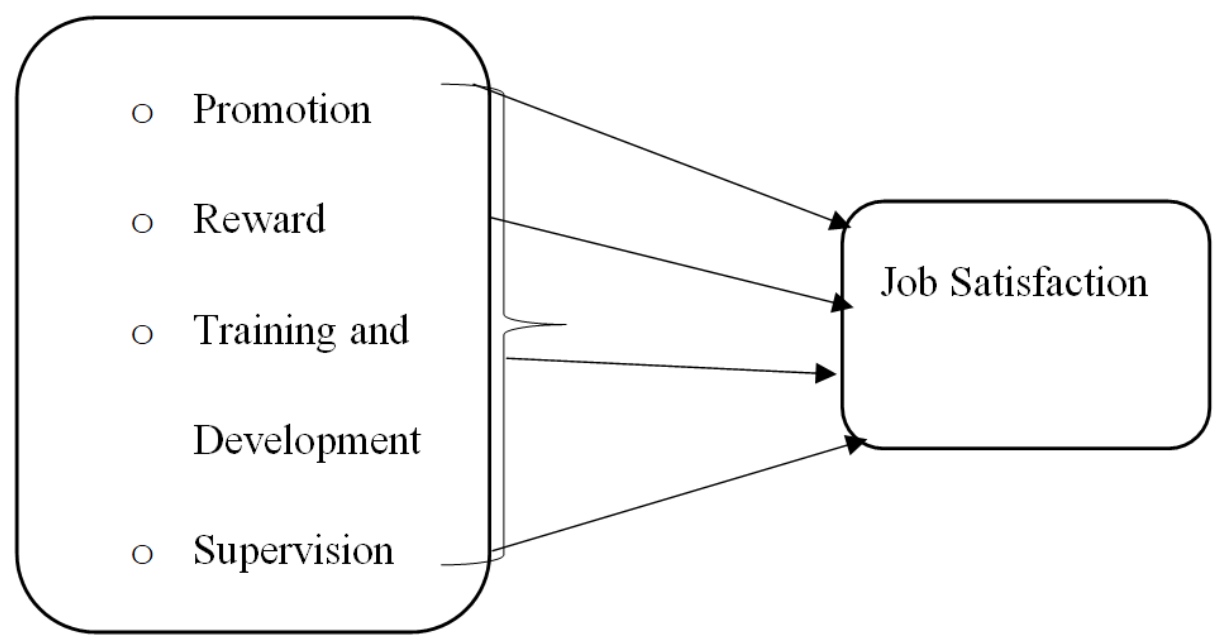

Figure 1. Conceptual Framework

Figure 1 portrays the influence of HRM practices on employees' job happiness. The following had been considered as factors determining workers' job satisfaction- promotion, reward, training and development, and supervision. Thus job satisfaction was evaluated based on the effect of the four variables in the employees' careers. This is to say that these HRM practices will express the degree to which senior staffs of UCC are pleased with the existing occupations.

\section{Methodology}

The study was explanatory. In gathering and analyzing data, a quantitative method was employed with a cross-sectional design. The University of Cape Coast (UCC) was selected based on practical reasons: (1) it is easy to get the cooperation of the staff during the research; (2) similar studies already exist in different aspects of HRM; and (3) its broad spectrum of HRM practices can easily help to measure workers' job satisfaction. The study was delimited to the 1469 Senior Staff employed at the university (DHR, 2019). Using Krejcie and Morgan's (1970) method in determining the sample size, a sample of 302 respondents was selected from the population of senior staff through a stratified random sampling technique. Primary data was collected for quantitative analysis using the questionnaire. A total number of 292 respondents answered the questionnaires, which represented $96.68 \%$ of the responses 
rate. The quantitative analysis was generated using the SPSS. Pearson correlation was employed to determine the associations among the variables. The standard multiple regression test was employed to determine the level of significance of each determinant to employees' job satisfaction in the university.

\section{Results of Findings}

Table 1. Gender of Respondents

\begin{tabular}{clcc}
\hline Gender & Frequency & Percent \\
\hline Valid & MALE & 134 & 45.9 \\
& FEMALE & 158 & 54.1 \\
& Total & 292 & 100.0 \\
\hline
\end{tabular}

Table 1 shows that $45.9 \%$ of the respondents were males and $54.1 \%$ were females.

Table 2: Descriptive Statistics

JS = Job Satisfaction; PR = Promotion; RE = Reward $; \mathrm{TD}=$ Training and Development SU $=$ Supervision.

\begin{tabular}{|l|c|c|c|}
\hline & Mean & Std. Deviation & N \\
\hline JS & 2.6541 & .75996 & 292 \\
\hline PR & 2.5377 & .79211 & 292 \\
\hline RE & 2.4452 & .85780 & 292 \\
\hline TD & 3.0514 & .65862 & 292 \\
\hline SU & 2.6884 & .68021 & 292 \\
\hline
\end{tabular}

Source: Survey data prepared by the researcher

The mean and standard deviation of HRM practices and employees' job satisfaction is shown in above Table 2. Training and development have a maximum mean value that is 3.051 while reward has a minimum mean value that is 2.445. The dependent variable which is job satisfaction has a mean value of 2.654. This implies that periodic training of staff helps them to acquire new skills that will enable them to work efficiently, which in turn can lead to job satisfaction.

\subsection{Correlation Matrix}

Pearson correlation was used to define the relationships among the variables. The results are presented in a correlation matrix in Table 3 . The investigation shows that all the HRM variables (PR, RE, TD, and SU) are related to employees' job satisfaction. This means that they affect the job satisfaction of UCC workers in one way or the other.

Table 3. Correlation Matrix for HRM practices and Job Satisfaction

\begin{tabular}{|l|l|c|c|c|c|c|}
\hline \multicolumn{2}{|l|}{} & JS & PR & RE & TD & SU \\
\hline JS & Pearson Correlation & & .025 & $.147^{*}$ & .070 & $.216^{* *}$ \\
& Sig. (2-tailed) & 1 & .676 & .012 & .233 & .000 \\
& $\mathrm{~N}$ & & 292 & 292 & 292 & 292 \\
\hline
\end{tabular}




\begin{tabular}{|l|l|l|c|c|c|c|}
\hline PR & Pearson Correlation & & & $.375^{* *}$ & $.177^{* *}$ & -.020 \\
& Sig. (2-tailed) & & 1 & .000 & .002 & .739 \\
& $\mathrm{~N}$ & & 292 & 292 & 292 \\
\hline RE & Pearson Correlation & & & & $.154^{* *}$ & .097 \\
& Sig. (2-tailed) & & 1 & .008 & .097 \\
& $\mathrm{~N}$ & & & 292 & 292 \\
\hline TD & Pearson Correlation & & & & & $.143^{*}$ \\
& Sig. (2-tailed) & & & & .014 \\
& $\mathrm{~N}$ & & & & 292 \\
\hline SU & Pearson Correlation & & & & & \\
& Sig. (2-tailed) & & & & & \\
& $\mathrm{N}$ & & & & & \\
\hline
\end{tabular}

*. Correlation is significant at the 0.05 level (2-tailed).

**. Correlation is significant at the 0.01 level (2-tailed).

Source: Survey data prepared by the researcher

\section{Relationship between promotion and job satisfaction}

The association between PR and JS is $r=0.025$ ( $p>0.05)$, which indicates that there is very little relationship between PR and JS. The coefficient of determination is 0.0625 . This means that only $6.25 \%$ of the variance of JS can be explained by PR. The remaining $93.75 \%$ of the variation is explained by extraneous variables. Notwithstanding we accept hypothesis $\mathrm{H}_{1}$ that there is a positive relationship between promotion and job satisfaction and reject $\mathrm{H}_{0}$ that there is a negative relationship between promotion and job satisfaction.

\section{Relationship between reward and job satisfaction}

The correlation between RE and JS is $\mathrm{r}=0.147(\mathrm{p}<0.05)$, which shows a moderate positive and significant relationship between RE and JS. The coefficient of determination of 0.0216 indicates that just $2.16 \%$ of the variance of JS can be explained by RE. Nevertheless, we accept hypothesis $\mathrm{H}_{2}$ that there is a positive relationship between reward and job satisfaction and reject $\mathrm{H}_{0}$ that there is a negative relationship between reward and job satisfaction.

\section{Relationship between training and development and job satisfaction}

The correlation between TD and JS is $r=0.070(\mathrm{p}>0.05)$, which indicates that they are not correlated. There is very little association between TD and JS. Since the coefficient of determination is 0.0049 , it can be said that only $0.49 \%$ of the variance of JS can be explained by TD. However, due to the correlation results, we accept hypothesis $\mathrm{H}_{3}$ that there is a positive relationship between training and development and job satisfaction and reject $\mathrm{H}_{0}$ that there is a negative relationship between training and development and job satisfaction.

\section{Relationship between supervision and job satisfaction}

The correlation between SU and JS is $\mathrm{r}=0.216(\mathrm{p}<0.05)$, which indicates a moderate positive 
and significant relationship between SU and JS. The coefficient of determination is 0.046. This means that $4.6 \%$ of the variance of JS can be explained by SU. Looking at the correlation results, we accept hypothesis $\mathrm{H}_{4}$ that there is a positive relationship between supervision and job satisfaction, and reject $\mathrm{H}_{0}$ that there is a negative relationship between supervision and job satisfaction.

Besides, there is a statistically significant positive correlation between $R E$ and $P R(r=0.375$, $\mathrm{p}<0.01$ ), meaning that reward increases as employees are promoted. There is therefore a positive correlation between $\mathrm{TD}$ and $\mathrm{PR}(\mathrm{r}=0.177, \mathrm{p}<0.05)$, meaning training and development increases the chance of the employees being promoted. The correlation coefficient between SU and PR is $r=-0.020$ ( $p>0.05$ ). This means that supervision decreases as employees are promoted to high positions. There is a positive correlation between TD and $\mathrm{RE}(\mathrm{r}=0.154, \mathrm{p}<0.05)$, meaning training and development increases the chance of employees to have more rewards (since TD can lead to promotion). Again, there is a positive correlation between SU and TD $(r=0.143, p<0.05)$, meaning that supervision is a form of training and development. The correlation between SU and RE is $r=0.097$ ( $p>0.05)$, which indicates that they are not correlated. Hence there is very little association between supervision of employees and reward.

\subsection{Regression Analysis}

A multiple regression analysis was performed to determine the predictors of employees' job satisfaction as conceptualized in the model. Tables 4 and 5 display the summary measure and ANOVA of the model and Table 6 show the coefficient for the predictors of job satisfaction.

Table 4. Predictors of Job Satisfaction- Model Summary

\begin{tabular}{|l|c|c|c|c|}
\hline Model & $\mathrm{R}$ & R Square & Adjusted R Square & Std. Error of the Estimate \\
\hline 1 & $.253^{\mathrm{a}}$ & .064 & .051 & .74038 \\
\hline
\end{tabular}

a. Predictors: (Constant), PR, RE, TD, SU

b. Dependent Variable: JS

Source: Survey data prepared by the researcher

Table 4 displays the values of $\mathrm{R}, \mathrm{R}$ square, adjusted $\mathrm{R}$ square, and standard error. $\mathrm{R}$ square indicates the amount of variation in the dependent variable (JS) that is accounted for by the independent variables (PR, RE, TD, SU). R of 0.253 shows the partial correlation between HRM practices and workers' job satisfaction. R square of 0.064 indicates that $6.4 \%$ of HRM practices adopted by UCC account for employees' job satisfaction. The remaining $93.6 \%$ of the variance is not explained by the variables depicted in this model.

Table 5. ANOVA

\begin{tabular}{|l|l|r|r|r|r|c|}
\hline \multicolumn{2}{|l|}{ Model } & Sum of Squares & Df & Mean Square & F & \multicolumn{1}{c|}{ Sig. } \\
\hline \multirow{3}{*}{1} & Regression & 10.742 & 4 & 2.686 & 4.899 & $.001^{\mathrm{b}}$ \\
\cline { 2 - 7 } & Residual & 157.323 & 287 & .548 & & \\
\cline { 2 - 7 } & Total & 168.065 & 291 & & & \\
\hline
\end{tabular}


Source: Survey data prepared by the researcher

The ANOVA Table 5 above measures the total significance of the model adopted for this study. Judging by the results, the overall model is significant as the significant value shows 0.001 which is less than 0.05 at a $95 \%$ confidence interval. Therefore, the model construct is validated.

Table 6. Coefficients for predictors of Job Satisfaction

\begin{tabular}{|l|l|c|c|c|c|c|}
\hline \multicolumn{2}{|c|}{} & \multicolumn{2}{|c|}{ Unstandardized Coefficients } & Standardized Coefficients & & \\
\cline { 2 - 7 } \multicolumn{2}{|l}{ Model } & $\mathrm{B}$ & Std. Error & Beta & $\mathrm{T}$ & Sig. \\
\hline \multirow{3}{*}{1} & (Constant) & 1.740 & .279 & & 6.244 & .000 \\
\cline { 2 - 7 } & Promotion & -.025 & .060 & -.026 & -.421 & .674 \\
\cline { 2 - 7 } & Reward & .119 & .055 & .134 & 2.154 & .032 \\
\cline { 2 - 7 } & $\begin{array}{l}\text { Training and } \\
\text { Development }\end{array}$ & .029 & .068 & .025 & .432 & .666 \\
\cline { 2 - 7 } & Supervision & .222 & .065 & .199 & 3.428 & .001 \\
\hline
\end{tabular}

Source: Survey data prepared by the researcher

The standardized regression model is:

$\mathrm{JS}=\alpha_{0}+\beta_{1} \mathrm{PR}+\beta_{2} \mathrm{RE}+\beta_{3} \mathrm{TD}+\beta_{4} \mathrm{SU}$

The fitted Regression Model is:

$\mathrm{JS}=1.740-0.026(\mathrm{PR})+0.134(\mathrm{RE})+0.025(\mathrm{TD})+0.199(\mathrm{SU})$

The above Table 6 displays the values of unstandardized and standardized beta coefficients and $t$ value. An unstandardized beta coefficient provides a measure of the contribution of each variable to the model. A larger value indicates that a unit change in the predictor variable has a larger impact on the criterion variable. Therefore the results show that the value of unstandardized beta coefficients is $0.025,0.119,0.029$, and 0.222 which is an indication of the influence of HRM practices on workers' job fulfillment. Looking at the significance column, one can see that only two variables (reward and supervision) made a statistically significant contribution. It can be seen that supervision (beta $=0.199$ ) is first followed by reward (beta $=0.134$ ). The beta values denote the contributions of each variable when the results of the other variables are statistically removed. This is in line with the significant values of supervision and reward which are 0.001 and 0.032 respectively, and which are less than 0.05 at a $95 \%$ confidence interval.

\section{Discussions and Implications}

This study aimed at assessing how HRM practices predict senior staffs' work happiness at UCC. A sample of 302 participants to whom a structured questionnaire was administered was selected, of which 292 respondents completed the questionnaires. Results revealed that two HRM practices- supervision and reward- potentially lead to job satisfaction among UCC workers. Looking at the beta value in Table 6, it can be said that supervision contributes about $19.9 \%$ to employees' job satisfaction. This result concurs with those of Hannang, Salju, 
and Qamaruddin (2020) and Nasution (2017) who argued that supervisors contribute significantly to every organization's high performance as they impact the requisite knowledge and skills on the workers. Hence Alam and Asim (2019) and Fukui, Wu, and Salyers (2019) noted that supervision is significantly associated with job satisfaction. This means that efficient supervisors potentially induce diligence and hard work in employees. Consequently, employees perform their duties diligently and better when they are under supervision.

This study also revealed that reward is a predictor of employees' job satisfaction at UCC. Besides the significance level (0.032), the beta value of Table 6 indicates that reward contributes about $13.4 \%$ to employees' job satisfaction. This is in line with the studies conducted by Terera and Ngirande (2014) and Chepkwony (2014) in which it is argued that reward is used to invite, stimulate, and keep hardworking and competent employees that can help the organizations achieve their stated goals; this can also be the case of UCC. For such a reason, Gohari et al (2013) suggested that the reward system should be designed in a way that will attract potential employees, and enhance employees' job satisfaction.

However, this study revealed that promotion is negatively related to employees' work satisfaction. Results in Table 6 show that the significance level and beta value for promotion were 0.675 and -0.026 respectively. This indicates that promotion does not necessarily contribute to employees' job satisfaction. This concurs with the study by Elqadri and Priyono (2015) in which they noted that promotion does not influence significantly job satisfaction. Lup (2017) confirmed that fact as he argued that promotion to managerial positions is complemented by an increase in job satisfaction for men but not automatically for women. This implies that the job satisfaction of women promoted to higher-level managerial positions often declines. This result can be accepted within the context of the study since Table 1 indicates that more women $(54.1 \%)$ were involved in the study than men (45.9\%).

Generally speaking, HRM practices in UCC influence staffs' work fulfillment. The results of Table 4 show that $6.4 \%$ of the variance in JS has been significantly explained by the combined effect of promotion, reward, training and development, and supervision. This justifies why the result of Table 5 posits HRM practices as the greatest predictor for employees' job satisfaction. This finding concurs with previous research findings by Vikram and Sayeeduzzafar (2014), Antwi et al. (2016), and Segbenya and Ansah (2020). It is also consistent with the results reported in similar studies by Absar et al. (2010), Farahbod and Arzi (2014), and Bharadwaj (2015) in which it is argued that there was a significant positive relationship between HRM practices and employees' job satisfaction. Thus this justifies the adoption of social exchange theory (Homans, 1961; Blau, 1964; Thibaut \& Kelley, 1959) as the theoretical underpinning for this study since job satisfaction involves both employees' behavior in organizations and interpersonal relationships.

\section{Conclusion and Suggestions for Future Research}

HRM practices are managerial activities that are usually performed to serve the interest of employees and at the same time help organizations to achieve desired objectives. The findings of the current study revealed that by paying more attention to supervision and reward, employees of the universities in Ghana will be satisfied with their jobs. The study was limited 
to assessing the relationship of HRM predictors with workers' satisfaction at UCC. To complement and have further insight into the issue under discussion, further investigations on the same subject matter can be conducted in other institutions of higher learning. Besides, related studies can be conducted longitudinally to assess the relationship between HRM practices and job satisfaction over time. The sample size consisted of senior staff of UCC only. Further studies can be conducted among senior members and junior staff workers to ascertain whether or not the influence of HRM practices is the same on all the workers of the University. Additional comparison studies can be done to ascertain the effect of HRM practices on workers of two different universities, and even different organizations in a quest to compare the effect of the variables on each corporate entity.

\section{References}

Absar, M. M. N., Azim, M. T., Balasundaram, N., \& Akhter, S. (2010). Impact of Human Resources Practices on Job Satisfaction: Evidence from Manufacturing Firms in Bangladesh. Economic Sciences Series. The Petroleum-Gas University of Ploiesti Bulletin, 62(2), 31-42.

Agwu, M. O. (2013). Impact of fair reward system on employees' job performance in Nigerian Agip Oil Company Limited Port-Harcourt. British Journal of Education, Society \& Behavioural Science, 3(1), 47-64. https://doi.org/10.9734/BJESBS/2013/2529

Alam, A., \& Asim, M. (2019). Relationship between Job Satisfaction and Turnover Intention. International Journal of Human Resource Studies, $9(2)$. https://doi.org/10.5296/ijhrs.v9i2.14618

Almatrooshi, B., Singh, S. K., \& Farouk, S. (2016). Determinants of organizational performance: a proposed framework. International Journal of Productivity and Performance Management, 65(6), 844 - 859. https://doi.org/10.1108/IJPPM-02-2016-0038

Antwi, J. O., Opoku, A. C., Ampadu S., \& Osei-Boateng M. (2016). Assessing the human resource management practices of public banks from employees' perspective: a case study of selected branches of Ghana Commercial Bank, Kumasi. Global Journal of Human Resource Management, 4(1), 13-30.

Bharadwaj (2019). HR Policies as Predictor for Employees Satisfaction in Delhi Metro Rail Corporation. Adhyayan, 9(1). https://doi.org/10.1504/IJSSCA.2020.10037734

Bharadwaj, Y. P. (2015). Impact of Human Resource Practices on Job Satisfaction with Special Reference to Delhi Metro Rail Corporation. International Journal of Engineering Technology, Management, and Applied Sciences, 3, 2349-4476.

Blau, P. M. (1964). Exchange and power in social life. NY: John Wiley \& Sons.

Božović, J., Božović, I., \& Ljumović, I. (2019). Impact of HRM Practices on Job Satisfaction of Employees in the Serbian Banking Sector. Journal of Sustainable Business and Management Solutions in Emerging Economies, 1, 63-77. https://doi.org/10.7595/management.fon.2018.0035

Chepkwony, C. C. (2014). The Relationship between Rewards Systems and Job Satisfaction A Case Study at Teachers Service Commission-Kenya. European Journal of Business and Social Sciences, 3(1), 59-70.

Cross, O. D. (2020). Employee rewards policy and its influence on organizational 
performance. International Journal of Research Science \& Management, 6(3).

Danish, R. Q., \& Usman, A. (2010). Impact of Reward and Recognition on Job Satisfaction \& Motivation: An Empirical Study from Pakistan. International Journal of Business and Management, 5(2). https://doi.org/10.5539/ijbm.v5n2p159

Edirisooriya, W. A. (2014). Impact of Rewards on Employee Performance: With Special Reference to ElectriCo., Proceedings of the 3rd International Conference on Management and Economics, 5, 311-318. https://doi.org/10.1002/9781118785317.weom060146

Eerde, W. V. (2015). Motivation and reward systems. Wiley Encyclopedia of Management.

Elqadri, Z. M., \& Priyono (2015).The Influence of Organizational Culture, Organizational Climate, and the Promotion of the Position of Employee Job Satisfaction in PT. Surabaya Graphics Media Temprina. Asian Social Science, 11(22). https://doi.org/10.5539/ass.v11n22p139

Emerson, R. M. (1976). Social exchange theory. Annual Review of Sociology, 2, 335-362. https://doi.org/10.1146/annurev.so.02.080176.002003

Farahbod, L., \& Arzi, S. (2014). Impact of Human Resource Management Practices on Employee Job Satisfaction: A Study of Malaysian Hotels. Interdisciplinary Journal of Contemporary Research in Business. Institute of Interdisciplinary Business Research, 6(3), 73-90.

Fukui, S., Wu, W., \& Salyers, M. P. (2019). Impact of Supervisory Support on Turnover Intention: The Mediating Role of Burnout and Job Satisfaction in a Longitudinal Study. Administration and Policy in Mental Health and Mental Health Services Research, 46(4), 488-497. https://doi.org/10.1007/s10488-019-00927-0

Giao, H. N. K., Vuong, B. N., \& Tushar, H. (2020). The impact of social support on job-related behaviors through the mediating role of job stress and the moderating role of locus of control: Empirical evidence from the Vietnamese banking industry, Cogent Business \& Management, 7(1). https://doi.org/10.1080/23311975.2020.1841359

Gohari, P., Kamkar, A., Jafar, S., Hosseinipour, R., \& Zohoori, M. (2013). Relationship between Rewards \& Employee Performance: A Mediating Role of Job Satisfaction. Interdisciplinary Journal of Contemporary Research in Business, 5, 3.

Gürbüz, S. (2009). The effect of high-performance HR practices on employees' job satisfaction. Istanbul University Journal of the School of Business Administration, 38, $110-123$.

Hannang, A. S., \& Qamaruddin, M. Y. (2020). The Effect of Supervision Levels on Employees' Performance Levels. Advances in Social Science, Education and Humanities Research, 477. https://doi.org/10.2991/assehr.k.201017.001

Hasan, M. N., Afrin, S., Rahman, M., \& Ahmed, A. A. A. (2020). Assessing the Nature of Job Satisfaction Level: A Study on Private Bank Employees in Bangladesh. Global Disclosure of Economics and Business, 9(2). https://doi.org/10.18034/gdeb.v9i2.511

Homans, G. C. (1958). Social behavior as exchange. American Journal of Sociology, 63, 597-606. https://doi.org/10.1086/222355

Homans. G. C. (1961). Social behavior. NY: Harcourt Brace. 
Igbal, H. K, Malik, M. E., \& Muhammad, M. G (2013). Impact of HR Practices on Job Satisfaction: Empirical Evidence from corporate sector of Punjab- Pakistan. Interdisciplinary Journal of Contemporary Research in Business, 5(2), 442-454.

Ismail, N. (2018). Iowa high school agriculture teachers' motivations to teach, personal and professional needs, and career satisfaction in the teaching profession. Graduate Theses and Dissertations.

Jehanzeb, K., \& Bashir, N. A. (2013). Training and Development Program and its Benefits to Employee and Organization: A Conceptual Study. European Journal of Business and Management, 5(2).

Johnson, R. D., \& Gueutal, H. G. (2011). Transforming HR through Technology: The Use of E-HR and HRIS in Organizations. Society for Human Resource Management Foundation.

Khan, I., Nawaz, A., \& Khan, M. S. (2013). Determining the Organizational Commitment of Academicians in Public Sector Universities of Developing Countries like Pakistan. International Journal of Academic Research in Accounting, Finance and Management Sciences, 3(1), 280-289.

Khan, M. A. (2010). Effects of Human Resource Management Practices on Organizational Performance - An Empirical Study of Oil and Gas Industry in Pakistan. European Journal of Economics, Finance, and Administrative Sciences.

Khan, R. A. G., Khan, F. A., \& Khan, M. A. (2011). Impact of Training and Development on Organizational Performance. Global Journal of Management and Business Research, 11(7).

Kosi, I., Opoku-Danso, A., \& Ofori, A. A. S. (2015). HRM Practices and Retention: An Empirical Study of Senior Staff of the University of Cape Coast. International Journal of Technology Enhancements and Emerging Engineering Research, 3(11), 2347-4289.

Krejcie, R. V., \& Morgan, D. W. (1970). Determining sample size for research activities: Educational and psychological measurement. New York: SAGE Publications Inc. https://doi.org/10.1177/001316447003000308

Kwenin, D. O., Muathe, S., \& Nzulwa, R. (2013). The Influence of Employee Rewards, Human Resource Policies and Job Satisfaction on the Retention of Employees in Vodafone Ghana Limited. European Journal of Business and Management, 5(12).

Locke, E. A. (1976). The handbook of industrial and organizational psychology. New York: Wiley.

Lup, D. (2017). Something to celebrate (or not): The differing impact of promotion to the manager on the job satisfaction of women and men. Work, employment and society, 1-19. https://doi.org/10.1177/0950017017713932

Malaolu, V. A., \& Ogbuabor, J. E. (2013). Training and Manpower Development, Employee Productivity and Organizational Performance in Nigeria: an Empirical Investigation, International Journal of Advances in Management and Economics, 2(5), 16+3-177.

Manzoor, F., Wei, L., \& Asif, M. (2021). Intrinsic rewards and employee's performance with the mediating mechanism of employee's motivation. Frontiers Psychology. https://doi.org/10.3389/fpsyg.2021.563070

Mensah, R. D. (2013). Principles of Human Resource Management. London: Xlibris. 
Miao, S., Fayzullaev, A. K. U., \& Dedahanov, A. T. (2020). Management Characteristics as Determinants of Employee Creativity: The Mediating Role of Employee Job Satisfaction. Sustainability, 12. https://doi.org/10.3390/su12051948

Mitchell, M. S., Cropanzana, R. S., \& Quisenberry, D. M. (2012). Social exchange theory, exchange resources, and interpersonal relationships: A modest resolution of theoretical difficulties. In K. Törnblom \& A. Kazemi (Eds.), Handbook of Social Resource Theory: Theoretical Extensions, Empirical Insights, and Social Applications, (pp. 99-118.) NY, NY: Springer. https://doi.org/10.1007/978-1-4614-4175-5_6

Molm, L. D. (2003). Theoretical comparisons and forms of exchange. Sociological Theory, 21(1), 1-17. https://doi.org/10.1111/1467-9558.00171

Muhammad, N., \& Akhter, M. (2010). Supervision, Salary, and Opportunities for Promotion as Related to Job Satisfaction, ASA University Review, 4(1).

Nassazi, N. (2013). Effects of Training on Employee Performance: Evidence from Uganda, Dissertation, Vaasan Ammattikorkeakoulu University of Applied Sciences.

Nasution, M. I. (2017). The influence of supervision and work discipline on the performance of state civil apparatus. Proceeding 3rd Sriwijaya Economics, Accounting, and Business Conference.

Niazi, M. M. K. (2014). Impact of Human Resource Practices on Job Satisfaction: A study of textile industry of Pakistan. International Journal of Management \& Organizational Studies, 3(1), 26-31.

Osborne, S., \& Hammoud, M. S. (2017). Effective Employee Engagement in the Workplace. International Journal of Applied Management and Technology, 16(1), 50-67. https://doi.org/10.5590/IJAMT.2017.16.1.04

Oyeniyi, K. O., Afolabi, M. A., \& Olayanju, M. (2014). Effect of Human Resource Management Practices on Job Satisfaction: An Empirical Investigation of Nigeria Banks. International Journal of Academic Research in Business and Social Sciences, 4(8), 243-251. https://doi.org/10.6007/IJARBSS/v4-i8/1093

Parker, R. A. (2008). Human Resource Handbook: A Guide to Effective Employee Management. Hardware Foundation: Indiana.

Polatcan, M., \& Cansoy, R. (2019). Examining studies on the factors predicting teachers' job satisfaction: A systematic review. International Online Journal of Education and Teaching, 6(1), 116-134. https://doi.org/10.16986/HUJE.2019054890

Pule, S., Mwesigye, J., Kanyangabo, E., \& Mbago, R. (2014). Human Resource Policy and Job Satisfaction of Employees in Knowledge-Based Enterprises: A Comparative Study of the Indigenous and Expatriate Teaching Staffs of Kampala International University, Uganda. Global Journal of Human Resource Management, 2(3), 13-27.

Qasim, S., Cheema, F. E. A., \& Syed, N. A. (2012). Exploring Factors Affecting Employees Job Satisfaction at Work. Journal of Management and Social Sciences, 8(1), 31 - 39. https://doi.org/10.46745/ilma.jbs.2012.08.01.04

Qian, J., Song, B., \& Wang, B. (2017). Abusive supervision and job dissatisfaction: The moderating effects of feedback avoidance and critical thinking. Frontiers in Psychology. https://doi.org/10.3389/fpsyg.2017.00496 
Qureshi, M. A., \& Hamid, K. B. A. (2017). Impact of Supervisor Support on Job Satisfaction: A Moderating role of Fairness Perception. International Journal of Academic Research in Business and Social Sciences, 7(3).

Redmond, M. V. (2015). "Social Exchange Theory". English Technical Reports and White Papers 5.

Rodriguez, J., \& Walters, K. (2017). The Importance of Training and Development in Employee Performance and Evaluation. World Wide Journal of Multidisciplinary Research and Development, 3(10), 206-212.

Saani, A. J., \& Tawiah, M. A. (2017). Effects of Compensation on the Work Performance of Junior Staff of the University of Cape Coast, Ghana. International Journal of Academic Research in Business and Social Sciences, 7(9). https://doi.org/10.6007/IJARBSS/v7-i9/3321

Salah, M. R. A. (2016). The Influence of Rewards on Employees Performance. British Journal of Economics, Management \& Trade, 13(4), 1-25.

Segbenya, M., \& Ansah, J. (2020). Influence of Human Resource Management Practices on Organizational Performance at Atwima Mponua Rural Bank Limited. Journal of Business and Enterprise Development, 9. https://doi.org/10.47963/jobed.2020.08

Soale, B., \& Akudugu, M. A. (2021). Employees' Attitude and their Performance: A Study of Senior Staff of the University of Cape Coast. International Journal of Scientific Research and Management, 9(4). https://doi.org/10.18535/ijsrm/v9i04.el01

Syed, N., \& Yah, L. X. (2012). Impact of High-Performance Human Resource Management Practices on Employee Job Satisfaction: Empirical Analysis. Interdisciplinary Journal of Contemporary Research in Business, 4(2), 318-342.

Terera, S. R., \& Ngirande, H. (2014). The Impact of Rewards on Job Satisfaction and Employee Retention. Mediterranean Journal of Social Sciences, MCSER Publishing, Rome, 5(1). https://doi.org/10.5901/mjss.2014.v5n1p481

Thibaut, J. W., \& Kelley, H. H. (1959). The social psychology of groups. NY: John Wiley \& Sons.

Thobega, M. (2007). Relationship of Supervision with Job Satisfaction and Retention of High School Agriculture Teachers. Moretti Thobega, Iowa State University Greg Miller, Iowa State University.

Timsal, A., Awais, M., \& Shoaib, O. (2016). On job Training and Its Effectiveness: An Employee Perspective. South Asian Journal of Banking and Social Sciences, 02(01).

Vann, J. C. (2017). Relationships between Job Satisfaction, Supervisor Support, and Profitability among Quick Service Industry Employees. Walden University ScholarWorks.

Vasanthi, S., \& Basariya, S. R. (2019). Pros and Cons of On the Job training versus Off the Job Training. International journal of scientific \& technology research volume 8, issue 10.

Vikram, J., \& Sayeeduzzafar, D. R. (2014). A Study of HRM Practices and its Impact on Employees job Satisfaction in Private Sector Banks: A Case Study of HDFC Bank. International Journal of Advanced Research in Computer Science and Management Studies, 2(1), 62-68. 
Appendix A. Distribution of Population by Rank and College

\begin{tabular}{lccccc}
$\begin{array}{lccc}\text { RANK } \\
\text { COLLEGE }\end{array}$ & CAA & PAA & SAA & AA & TOTAL \\
\hline CODE & & & & & \\
CES & 9 & 59 & 31 & 2 & 101 \\
CHLS & 21 & 45 & 62 & 2 & 130 \\
CHAS & 29 & 39 & 80 & 8 & 156 \\
CANS & 6 & 45 & 27 & 2 & 80 \\
CA & 29 & 57 & 74 & 16 & 176 \\
SGRS & 209 & 293 & 159 & 65 & 726 \\
ULIB & 1 & 4 & 6 & - & 11 \\
\hline TOTAL & 37 & 30 & 18 & 4 & 89 \\
\hline
\end{tabular}

Source: Directorate of Human Resource, University of Cape Coast (May 2019)

Appendix B. Distribution of Sample Size by Rank and College

\begin{tabular}{lccccc}
\hline RANK & CAA & PAA & SAA & AA & TOTAL \\
COLLEE & & & & & \\
\hline CODE & 2 & 12 & 6 & - & 20 \\
CES & 4 & 9 & 13 & - & 26 \\
CHLS & 6 & 8 & 16 & 2 & 32 \\
CHAS & 1 & 9 & 6 & - & 16 \\
CANS & 6 & 12 & 15 & 3 & 36 \\
CA & 43 & 61 & 33 & 14 & 151 \\
SGRS & - & 1 & 1 & - & 2 \\
ULIB & 8 & 6 & 4 & 1 & 19 \\
\hline TOTAL & 70 & 118 & 94 & 20 & 302 \\
\hline
\end{tabular}

Source: Field survey (2019)

The formula for determining the sample size for each stratum is: $s=\frac{\mathrm{n}}{\mathrm{N}} \times \mathrm{Z}$ where

$\mathrm{s}=$ sample size for each stratum (category)

$\mathrm{n}=$ number of workers in a stratum

$\mathrm{N}=$ total population of senior staff

$\mathrm{Z}=$ sample size of the population of interest

\section{Copyright Disclaimer}

Copyright for this article is retained by the author(s), with first publication rights granted to the journal.

This is an open-access article distributed under the terms and conditions of the Creative Commons Attribution license (http://creativecommons.org/licenses/by/4.0/). 